\title{
Poradnictwo karier w sektorze szkolnictwa zawodowego - refleksje - dylematy - pytania
}

\section{KEY WORDS}

vocational career, career (vocational) guidance, vocational education system, career coaching

\begin{abstract}
Piorunek Magdalena, Poradnictwo karier w sektorze szkolnictwa zawodowego - refleksje - dylematy - pytania [Career Counselling in the Sector of Professional Education: Reflections, Dillemas and Questions]. Kultura - Społeczeństwo - Edukacja nr 2(10) 2016, Poznań 2016, pp. 43-58, Adam Mickiewicz University Press. ISSN 2300-0422. DOI 10.14746/kse.2016.10.4.

The text brings closer the career (vocational) guidance issues in the context of the vocational education specificity. Liquid modernity, with multidirectional changes occurring at a great speed, and growing requirements of the competitive labour market have become fertile soil for the growth of all sorts of guidance services, i.e. activities that concern the entire human life and treat individuals in a holistic way. Being one of them, the career guidance has travelled a long way undergoing a paradigmatic change of its objectives and tasks and of other aspects, i.e. how a relation with a client starts or what methods are applied. Vocational school students are one of those groups where career structuring is in demand. Being a weak link in Poland's education system before the economic and political system transformations of 1989, after this date the group actually has started drifting, losing to the growing educational aspirations and the boom of secondary education that opened the door to increasingly popular higher education. Current efforts to restore vocational education need to be coupled with career guidance services that are provided professionally to the present and future vocational school students. Assumptions of these career guidance activities do not seem to differ basically from the general assumptions applied in the holistic guidance, which does not mean that a search for methods suited to this group of young people should be discontinued.
\end{abstract}

${ }^{*}$ Treści zawarte w niniejszym artykule stanowią także kanwę tekstu autorskiego: Poradnictwo zawodowe w kontekście potrzeb uczniów szkolnictwa zawodowego, „Polityka Społeczna” 2016, nr 9. 


\section{Poradnictwo w płynnej nowoczesności}

W epoce Baumanowskiej płynnej ponowoczesności (Bauman, 2006; 2007a; 2007b) czy Giddensowskiej późnej nowoczesności (Giddens, 2007) często zmianie ulegają niemal wszystkie parametry funkcjonowania jednostek, co stwarza nowe wyzwania, stawia przed nowymi wyborami, daje szanse i możliwości, ale przynosi też nowe problemy i zagrożenia, poszerza obszary niepewności i biograficznego ryzyka (Beck, 2002). Rodzi także zapotrzebowanie na pomoc i wsparcie społeczne w zmaganiach z codziennością (Piorunek, 2010; 2011; Piorunek, Kozielska, Skowrońska-Pućka, 2013).

Zmianom o charakterze makrospołecznym i kulturowym towarzyszą szczególnie intensywne przemiany sfery pracy i zawodowego funkcjonowania ludzi, wynikające również z dekonstrukcji centralnie sterowanej gospodarki i dominacji swobodnej gry rynkowej po pierwszych wolnych wyborach w 1989 roku.

Ubocznym kosztom skoku cywilizacyjnego związanego $\mathrm{z}$ transformacją ustrojowo-gospodarczą ostatniego dwudziestopięciolecia i nowych wyzwań konkurencyjnej gospodarki wolnorynkowej, której wymagania zasadniczo różniły się od wcześniejszych, towarzyszą także bliskie i długofalowe skutki kolejnych mniejszych i większych załamań, kryzysów gospodarki europejskiej i światowej. Narastająca konkurencja na rynku pracy prowadzi do powiększania się liczby jednostek i grup marginalizowanych czy wręcz wykluczanych poza nawias społeczeństwa, ale także wymusza intensyfikację działań wszystkich uczestników tego rynku w celu zajęcia i utrzymania swojej nań pozycji.

Zupełnie nieznanym przed ćwierćwieczem zjawiskiem na krajowym rynku pracy pozostawało bezrobocie i konieczność wielokrotnego aktywnego lokowania się na rynku pracy związana ze stałą konfrontacją osobistych zasobów, kompetencji, kwalifikacji z aktualnymi, najczęściej czasowo obowiązującymi, często niejednoznacznymi wymaganiami owego rynku. Niebagatelne znaczenie w tym procesie ma permanentna edukacja. Stosunkowo wysoką przewidywalność i liniowość doświadczeń zawodowych zastąpiła wielokierunkowość dyfuzyjnych doświadczeń rynkowych oraz wielokrotne tranzycje w obrębie rynku edukacji i pracy (por. Piorunek, 2009).

Narastające tempo życia codziennego, wzrastający poziom jego złożoności i nieprzewidywalności, co wymaga częstych zmian planów czy konstruowania projektów o wysokim stopniu elastyczności, a także stałej potencjalnej gotowości jednostki do działania i niemal natychmiastowego wdrażenia nowych technik adaptacyjnych, umożliwiających opanowywanie kolejnych wyzwań na rynku pracy - to dominujące rysy współczesności. 
Zmiana jako wartość rudymentarna, stająca się podstawą życia, powoduje, że jesteśmy zmuszeni do podejmowania coraz większej liczby decyzji życiowych, rodzinnych, zawodowych, często decyzji w sytuacjach niepewnych, ryzykowych o nieprzewidywalnych konsekwencjach dla naszego dalszego funkcjonowania. Wielość decyzji, trudne wybory o odroczonych konsekwencjach, emocjonalne dysonanse, kalejdoskop scenariuszy i wariantów, dyfuzja ról i obszarów aktywności, poszukiwanie kompromisów i sztuka rezygnacji, pozorne poczucie sprawstwa w codziennych decyzjach przy całkowitym jego braku w kontekstach makrospołecznych, gra społeczna o skomplikowanych, dynamicznie zmieniających się regułach, odmiennych od dotychczasowych - to elementy deskrypcji warunków życia wielu grup ludzi.

Wspomniane przemiany kulturowe dotyczą zarówno sfery życia rodzinnego, jak i zawodowego. Można dokonywać ich oglądu w perspektywie makrospołecznej (socjologicznej, ekonomicznej, kulturoznawczej), ale także opisywać i analizować fenomeny codzienności pojedynczych osób.

Jednocześnie ponowoczesna kultura indywidualizmu z jakże często egocentryczną koncentracją na jednostce i jej osobistych potrzebach, z powierzchownością międzyludzkich kontaktów (często wirtualnych) przynosi w efekcie rozluźnienie więzi międzyludzkich oraz ograniczenie roli naturalnych grup wsparcia $\mathrm{w}$ rozwiązywaniu problemów i zmaganiu się z codziennością.

Wszystkie te zjawiska o podłożu kulturowo-gospodarczym odciskają szczególne piętno na życiu młodzieży. Adolescencja bowiem, stanowiąca swoisty pasaż pomiędzy dzieciństwem i dorosłością, sama w sobie jest okresem szczególnych wyzwań, przed jakimi staje młody człowiek, starając się odpowiedzieć na pytanie o to, kim de facto jest i „staje się" oraz kim zamierza być w przyszłości (por. na przykład Harwas-Napierał, Trempała, 2014). Adolescencja zaś, przebiegająca w warunkach permanentnych zmian społecznego kontekstu dorastania, przyczynia się do konstruowania licznych, czasowo obowiązujących tożsamości, które kreuje się w zderzeniu pomiędzy edukacyjną codziennością, wymaganiami, rynku pracy, na który młodzi niebawem wkroczą, a popkulturowymi modami (Melosik, 2014). Często także, na skutek nieadekwatności działań, form życia i reguł je legitymizujących w pokoleniu rodziców w stosunku do teraźniejszego funkcjonowania młodego człowieka nieprzydatne staje się ich odwzorowywanie i odwoływanie się do nich. Konieczne jest zatem szukanie innych, własnych dróg rozwoju w tym nowym świecie. W rzeczywistości także nowych wyzwań na rynku pracy.

W sukurs przychodzić może młodym ludziom profesjonalne poradnictwo, nierezerwowane zresztą tylko dla tej fazy życia, ale odniesione do całej biografii jednostki. 


\section{Zmiana paradygmatu poradnictwa}

Działania z zakresu poradnictwa dotyczącego przebiegu życia zawodowego jednostek określa się w dokumentach o zasięgu europejskim, na przykład Memorandum dot. kształcenia ustawicznego (2000), europejskim Programie uczenia sie przez całe życie (LLP) przewidzianym na lata 2007-2013 (decyzja z 2006), Rezolucji dotyczacej całożyciowego poradnictwa zawodowego $w$ Europie (2004), Rezolucji dotyczacej pragmatycznego wdrażania całożyciowego poradnictwa zawodowego w systemy kształcenia ustawicznego w Europie (2008) mianem poradnictwa zawodowego. Nazwa ta, upowszechniona w literaturze przedmiotu i świadomości społecznej już znacznie wcześniej, nawiązuje do zdobywania przez jednostkę określonego zawodu i lokowania się na rynku pracy w określonych sektorach gospodarki. Myślenie to, charakterystyczne dla epoki względnie stabilnego modernizmu, zakładało przewidywalność ludzkiego życia, jego powiązanie temporalne $\mathrm{z}$ określonymi instytucjami, zdobywanie zawodu określającego całożyciową tożsamość człowieka realizowanego w linearnym wzorcu kariery. Takiemu funkcjonowaniu jednostki przypisano pozytywistyczny model poradnictwa zawodowego, mającego na celu dobór określonej profesji do możliwości i kompetencji człowieka. Przemiany makrospołeczne późnej nowoczesności wraz z nurtem humanistycznym pojawiającym się od połowy ubiegłego wieku $\mathrm{w}$ naukach społecznych, a nasilające się $\mathrm{w}$ ponowoczesności, przyczyniają się z jednej strony - do przemian ludzkiego życia, które staje się mniej przewidywalne, poddane procesom permanentnych zmian, $\mathrm{z}$ drugiej - do zmian paradygmatu poradnictwa, dokonujących się w kilku płaszczyznach:

- zarówno w sferze indywidualnego traktowania klienta i działania w celu priorytetowego zaspokojenia potrzeb jednostkowych, nie zaś zapotrzebowania systemu makrospołecznego (Kargulowa, 2005);

- $\mathrm{w}$ sferze procesualnego postrzegania poradnictwa, nie zaś incydentalnego, statycznego kontaktu z klientem (Kargulowa, 2009);

- jak i w ramach ponowoczesnego modelu biografii zawodowej, traktującego życie jako czasowe odkrywanie tożsamości, której praca jest tylko elementem, a zadaniem jednostki staje się lokowanie pracy w przebiegu własnej biografii w celu optymalizowania sytuacji życiowej (Peavy, 2014).

Stąd pojawiają się w literaturze określenia: poradnictwo czy edukacja karier (Savickas, 2013; Savickas, 2013; Bańka, 2007), life design (Savickas, 2010), rzadziej poradnictwo biograficzne (Malewski, 2003; Piorunek, 2004). Zasadniczym celem tego zabiegu (nie tylko) semantycznego jest podkreślenie temporalnej struktury biegu życia zawodowego oraz konieczności zaakceptowania włączania weń zróżnicowanych doświadczeń na rynku pracy, które składają się na ostateczny kształt kariery; kariery postrzeganej jako konstrukt dualny, związany 
z obiektywnymi zadaniami podejmowanymi na rynku pracy, a także subiektywnie doświadczany przez jednostkę zakres aktywności edukacyjnej i zawodowej (Cybal-Michalska, 2013; Piorunek, w druku).

Dla potrzeb niniejszego opracowania definiuję pojęcie kariery jako wzoru doświadczeń życiowych związanych z pracą. Jest ona zatem konstruktem temporalnym, co oznacza, że wspieranie jednostki w jej konstruowaniu i przebiegu musi mieć także charakter diachroniczny, całożyciowy. Zdaniem autorów Memorandum dot. kształcenia ustawicznego (2000) wzrośnie zapotrzebowanie na profesjonalne usługi doradcze, ponieważ powinny one mieć charakter powszechny być stale dostępne dla szerokiego grona odbiorców w różnych fazach zawodowego rozwoju, na różnych etapach życia zawodowego.

Poradnictwo to realizowane jest $\mathrm{w}$ realiach polskich przede wszystkim $\mathrm{w}$ ramach instytucji doradczych działających w systemie edukacji (doradcy zawodowi w szkołach różnych typów i szczebli, wcześniejsza koncepcja szkolnych ośrodków kariery, poradnictwo w ramach poradni psychologiczno-pedagogicznych) oraz podległych Ministerstwu Pracy i Polityki Społecznej (tu opierają się w dużej mierze na aktywności urzędów pracy różnego szczebla). Spektrum tych instytucji i ośrodków profesjonalnej pomocy doradczej w zakresie konstruowania kariery jest oczywiście szersze (włączając $\mathrm{w}$ to instytucje o charakterze niepublicznym) i jako takie nie wyczerpuje znamion systemowości - to raczej instytucje współistniejące w przestrzeni społecznej, liczne bardzo zróżnicowane, często nie podejmujące współpracy, odznaczające się znaczną dynamiką i zmiennością wzorców aktywności i działalności pomocowej.

Zważywszy na specyfikę tematycznego zakresu niniejszego tekstu, interesujące jest przede wszystkim odniesienie poradnictwa kariery do etapu preparacyjnego i tranzycji z edukacji na rynek pracy, bowiem uczniowie szkolnictwa zawodowego, będąc w początkowej fazie rozwoju kariery zawodowej, jednocześnie wybrali potencjalnie najkrótszą z dróg edukacyjnych prowadzących na rynek pracy (w przeciwieństwie do ich kolegów ze średniego szkolnictwa ogólnokształcącego, prowadzącego w konsekwencji do kolejnych szczebli edukacji wyższej i odraczającego moment wyjścia na rynek).

\section{Uczniowie szkół zawodowych jako adresaci działań poradniczych}

Szkolnictwo zawodowe (zasadnicze szkoły zawodowe plus technika), do którego przed przełomem ustrojowym, $\mathrm{w}$ dobie centralnie sterowanej gospodarki trafiało około $3 / 4$ absolwentów ośmioletnich szkół podstawowych, przygotowywało przede wszystkim do podjęcia pracy zawodowej, koncentrując się w dużej mierze na 
aspektach praktycznych, niekoniecznie zresztą odpowiadających wysokim standardom kształcenia, rynek bowiem wchłaniał wszystkich kończących edukację. Każdy wychodzący na rynek pracę otrzymywał, nie zawsze odpowiadającą aspiracjom czy umożliwiającą realizację jednostkowych potrzeb, bez konkurowania jednak o miejsce na rynku. Młodzież wybierała zwłaszcza zasadnicze szkoły zawodowe na skutek selekcji negatywnej, stosunkowo często towarzyszył temu niski poziom rezultatów edukacyjnych i podejmowanie kształcenia w zawodach, w których nie zawsze zamierzało się poszukiwać zatrudnienia (por. na przykład Kaczor, 1989; Piorunek, 1992).

Boom edukacyjny początku lat dziewięćdziesiątych, związany ze wzrostem aspiracji edukacyjnych społeczeństwa i zwiększoną dostępnością do szkół ogólnokształcących na poziomie ponadgimnazjalnym ${ }^{1}$, a w dalszej perspektywie - szkolnictwa wyższego, które zaczęło się dynamicznie rozwijać także w sektorze edukacji niepublicznej, spowodował zmianę kształceniowych preferencji młodzieży. Niski poziom kształcenia i często wątpliwa renoma zasadniczych szkół zawodowych odstręczały wielu młodych od podejmowania edukacji w tym sektorze szkolnictwa, kierując zasadniczy strumień młodzieży do liceów ogólnokształcących, stanowiących bezpośrednią drogę do podejmowania studiów i otrzymywania upragnionych dyplomów uczelni wyższych. W krótkim czasie znacząco wzrósł odsetek uczniów liceów ogólnokształcących oraz osób uzyskujących w perspektywie wykształcenie wyższe. Ustawa o szkolnictwie wyższym z 12 września 1990 roku, która stworzyła możliwości „urynkowienia” edukacji poprzez pozbawienie państwa pozycji monopolisty w zakresie tworzenia szkół wyższych (możliwość tworzenia tzw. uczelni niepublicznych, których liczba zaczęła rosnąć lawinowo) oraz uruchamiania płatnych studiów wyższych na uczelniach publicznych (finansowanie przez studentów kształcenia w trybie niestacjonarnym), zapoczątkowała wspomniany boom w edukacji średniej ogólnokształcącej i wyższej. Zgodnie z danymi zawartymi w publikacji Społeczeństwo $w$ drodze do wiedzy. Raport o stanie edukacji 2010 mamy w Polsce, w porównaniu z innymi krajami europejskimi i Stanami Zjednoczonymi, najwyższy wskaźnik szkół niepublicznych i studentów kształcących się w tego typu szkołach. Wydłużanie etapu kształcenia o okres realizacji studiów wyższych odsuwało $\mathrm{w}$ czasie rzeczywisty udział młodych ludzi w rynku pracy, w tym realny ich udział w rosnącym bezrobociu.

Z kolei pozostawione samym sobie, nieunowocześniane, niedofinansowane szkoły zawodowe przestały przyciągać uczniów, bowiem atrakcyjniejsze dla mło-

${ }^{1}$ Z analiz E. Goźlińskiej i A. Kruszewskiego, Raportu KOWEZiU Stan szkolnictwa zawodowego w Polsce (2013) wynika, że w pierwszej dekadzie XXI wieku systematycznie rósł trend wyboru liceów ogólnokształcących przez absolwentów gimnazjów. W pewnym uproszczeniu można stwierdzić, że co najmniej 4 na 10 absolwentów gimnazjów wybierało ten typ szkolnictwa - s. 88 . 
dzieży i ich rodziców stały się dyplomy wyższych uczelni, które, jak się jednak wkrótce okazało, nie zapewniały automatycznie możliwości uzyskiwania zatrudnienia, a niska jakość części oferty edukacyjnej na tym poziomie oraz niedopasowanie jej do rzeczywistych potrzeb rynku pracy (na przykład znaczne poszerzenie "niskokosztowej” oferty studiów humanistycznych, których ukończenie nie gwarantuje zatrudnialności) dodatkowo tę trudną sytuację pogłębia. Jednocześnie coraz częściej na rynku pracy pojawia się zapotrzebowanie na określone praktyczne profesje, a fachowcy w wielu dziedzinach, często elementarnych dla codziennego funkcjonowania człowieka, są potrzebni, tyle że nikt ich nie kształci, dodać należy - na dobrym poziomie, zgodnie $\mathrm{z}$ duchem czasu $\mathrm{w}$ aspekcie kompetencyjno-warsztatowym i z poszanowaniem etosu pracy. Szkoły zawodowe przez lata dryfowały, a w opinii społecznej uchodziły, podobnie zresztą jak przed okresem transformacji, za „szkoły ostatniej szansy”, do których trafia się nie tyle $\mathrm{z}$ wyboru, co bez wyboru. Nader często szli do nich uczniowie bądź o niższych rezultatach edukacyjnych bądź z kolei - o sprecyzowanych planach zawodowych związanych na przykład z dziedziczeniem warsztatu pracy czy rodzinną tradycją. Szkoły zawodowe przed etapem transformacji ustrojowej nie były w wielu wypadkach miejscem wszechstronnego rozwoju uczniów, a zarzuty pod ich adresem można mnożyć. W praktyce jednak, zamiast dokonywania systematycznych reform, mieliśmy do czynienia raczej z eliminowaniem tych placówek $\mathrm{z}$ mapy szkolnictwa $\mathrm{w}$ kraju, mimo że wielu przedstawicieli nauk pedagogicznych podnosiło w przestrzeni publicznej szereg istotnych dylematów tego sektora szkolnictwa, wskazując jednocześnie na konieczność i kierunki pożądanych modyfikacji sprzyjających rozwojowi kształcenia zawodowego (Kwiatkowski, 2001; Piorunek, 2002; Kwiatkowski, 2008; Jeruszka, 2012).

Doraźnie pomóc wydobyć ten sektor edukacji z impasu mają dotacje unijne oraz realizowana przez Ministerstwo Edukacji Narodowej kampania społeczna (przynosząca $\mathrm{z}$ wolna efekty $\mathrm{w}$ postaci zwiększającego się zainteresowania młodzieży szkolnictwem zawodowym) dotycząca modernizacji (programowej, unowocześniania bazy dydaktycznej, realizacji praktyk i staży zawodowych u odpowiednio przygotowanych pracodawców) szkolnictwa tego sektora, skoncentrowana na ukazywaniu możliwości edukacyjno-zawodowych po ukończeniu tych szkół (na przykład jedna z kampanii promujących szkolnictwo zawodowe \#DOBRY ZAWODnik; rok 2015 - Rok Szkoly Zawodowców). Szkoły zawodowe mają szansę stać się przeciwwagą dla negatywnych efektów nie zawsze przemyślanych decyzji kształceniowo-zawodowych dotyczących szkolnictwa ogólnego i „nierynkowych” kierunków studiów (choć i tak poziom bezrobocia wśród osób z wyższym wykształceniem jest najniższy - por. Szafraniec, 2011). Sytuacja gospodarcza wymusza konieczność racjonalnego równoważenia osobistych preferencji i potrzeb rynku pracy w procesie budowania kariery przez młodych ludzi. 
Adolescenci - uczniowie szkół zawodowych, ale i pozostałych typów szkół potrzebują zatem pomocy w procesie aktywnego konstruowania swojej edukacyjno-zawodowej drogi. Obok wsparcia nieformalnego, na które często powołują się uczniowie (rodzice, inni członkowie rodzin, rówieśnicy), pomocne może okazać się profesjonalne poradnictwo (Piorunek, 2004). Sytuacja uczniów szkolnictwa zawodowego jest o tyle specyficzna, że, w przeciwieństwie do ich rówieśników podejmujących naukę w dłuższych cyklach kształcenia, oni będą musieli $\mathrm{z}$ wymaganiami rynku pracy zmierzyć się w krótkiej perspektywie czasowej, a ich edukacja nie pozostawia wielu szans na charakterystyczne dla psychospołecznego moratorium okresu adolescencji „próbowanie” ról osób dorosłych - oni stają się dorosłymi bardzo szybko, podejmując konkretne, wymierne $\mathrm{w}$ różnych aspektach życia role zawodowe.

\section{Refleksje o poradnictwie karier adresowanym do uczniów szkolnictwa zawodowego - swoistość czy uniwersalizm}

Stopień zaawansowania i specyfika procesu projektowania przyszłości edukacyjno-zawodowej przez młodzież wyznaczą zróżnicowane kręgi działań z zakresu poradnictwa zawodowego (poradnictwa karier) adresowanego do adolescentów ${ }^{2}$. Będą to w wielu przypadkach zabiegi związane ze wsparciem:

- informacyjno-orientacyjnym, ukazującym czynniki determinujące współczesną sytuację na rynku edukacji i pracy, wskazujące na specyfikę pracy w określonych profesjach;

- edukacyjnym, porządkującym możliwości realizacyjne biograficznych wyborów dorastających oraz ułatwiającym samopoznanie;

- w zakresie umiejętności planowania kariery, konstruowania kompleksowych projektów, przewidywania konsekwencji realizacji planów i uwzględniania środków ich realizacji a także podejmowania decyzji (por. Paszkowska-Rogacz, 2002).

Efektem takiego poradnictwa powinien stać się wzrost mocy decyzyjnej młodych oraz uświadamianie długodystansowego, kompleksowego charakteru decyzji zawodowych, którego młodzi nie zawsze dostrzegają. W dalszej zaś kolejności $\mathrm{w}$ wielu przypadkach zasadne staną się zarówno długofalowe działania, których celem będzie pomaganie uczniom $\mathrm{w}$ rozwijaniu kompetencji intelektualnych, emocjonalnych i behawioralnych, umożliwiających im przejęcie odpowiedzialności za kształtowanie własnej kariery zawodowej, jak i rozbudowane formy

\footnotetext{
${ }^{2}$ Zagadnienia prezentowane $\mathrm{w}$ niniejszym podrozdziale są przedmiotem rozważań autorki tekstu w kilku wcześniejszych publikacjach, por. między innymi Piorunek, 2004 i Piorunek, 2011.
} 
głębokiego indywidualnego wsparcia psychospołecznego realizowanego w miarę zgłaszanych potrzeb. Każdy z tych typów działań wymaga innych kompetencji doradców zawodowych (doradców kariery) funkcjonujących w ramach systemu edukacyjnego. Nie sposób jednak przecenić tu zwłaszcza kompetencji psychologiczno-pedagogicznych, których znaczenie będzie rosło zwłaszcza w obszarze rozpoznawania indywidualnych orientacji aksjonormatywnych, podmiotowego porządkowania dysonansowych obszarów społecznego chaosu, werbalizowania biograficznych celów oraz wewnętrznego sterowania karierą zawodową, której nieprzewidywalność i mobilność wielu odstręcza od planowania i osobistego w nią zaangażowania. W każdym jednak wypadku dogłębna znajomość funkcjonowania człowieka w okresie dorastania, jak i specyfiki adolescencyjnego projektowania edukacyjno-zawodowej przyszłości istotnie wpłyną na skuteczność świadczonych usług poradniczych.

Zasadniczym celem tak pojętej pomocy jest przygotowywanie jednostki do odpowiedzialnego kierowania swoją karierą, przy wykorzystaniu indywidualnych zasobów i kompetencji. Proces ten może przybierać formę odwołującego się do angloamerykańskich tradycji działającego w strukturze wewnątrzszkolnej subsystemu guidance (Watts i in., 1996; 1997), będącego specyficznym przewodnictwem, ciągłym towarzyszeniem człowiekowi w jego drodze edukacyjnej i rozwojowej. Istotą tego przewodnictwa jest stałe konfrontowanie dorastających z pytaniem „co zrobisz ze swoim życiem?”. Aby pytania te w ogóle stawiać i efektywnie na nie odpowiadać, niezbędne jest wcześniejsze przygotowanie i sukcesywne budowanie obrazu świata zawodowego i obrazu siebie samego, co w przyszłości doprowadzi do skonfrontowania obu tych zakresów deskryptywnych i ewaluatywnych w celu zadania pytań o to, jak ja moge funkcjonować w świecie zawodowym? Od tego pytania zaś tylko krok do projektowania i konstruowania swojej biografii zawodowej. Poradnictwo o charakterze specyficznego życiowego przewodnictwa wymaga także uzupełnienia o elementy subsystemu counseling, $\mathrm{w}$ którym autodiagnoza stanowi przede wszystkim środek do rozbudowywania samowiedzy i samooceny, zasadniczym celem zaś jest wsparcie w radzeniu sobie z zadaniami codziennego życia oraz doradztwo dla samopomocy.

Poradnictwo kariery to przede wszystkim niedyrektywny proces pomagania młodemu człowiekowi w poznawaniu siebie i świata pracy, wytyczaniu biograficznych priorytetów, dokonywaniu kolejnych wyborów, ich konfrontowaniu $\mathrm{z}$ realiami rynku.

Planowanie kariery musi się odbywać na innych niż dotychczasowe zasadach $\mathrm{w}$ płynnej rzeczywistości etapy preparacyjne (przygotowanie do podejmowania decyzji i nakreślanie krótkoterminowych planów) będą stale przeplatały się z etapami realizacyjnymi, a podjęte decyzje i skonstruowane plany będą wymagały zmiany, często zanim zostanie sfinalizowana ich realizacja. Częściej też zapewne realia podej- 
mowania decyzji i dokonywania wyborów wyznaczą wydarzenia bieżące. Coraz rzadziej będziemy też mogli myśleć w kategoriach docelowego, dookreślonego zawodu jako konstruktu zamkniętego, wyznaczającego jednoznacznie trajektorię naszego zaangażowania na rynku pracy, a poszczególne warianty decyzji edukacyjno-zawodowych będą podlegały procesowi stałej ewaluacji i wielokrotnego wyboru. Uzyskiwane kompetencje i zdobywane doświadczenia, także umiejętnie wykorzystywane aktualne szanse zawodowe, przy dobrze zdefiniowanych priorytetach życiowych, ale także dużej elastyczności w dążeniu do ich realizacji, mogą nam potencjalnie stworzyć szanse na sukces na rynku pracy.

W różnych krajach Unii Europejskiej problemy uruchamiania wsparcia dla młodzieży dokonującej wyborów edukacyjnych i zawodowych rozwiązywane są w zróżnicowany sposób w zależności od tradycji i specyfiki lokalnej. Dominują zróżnicowane grupowe i indywidualne formy świadczenia pomocy dla młodzieży. Możemy wśród nich wyliczyć na przykład następujące (Trzeciak, Drogosz-Zabłocka, 1999: 39):

- udzielanie informacji o możliwościach edukacyjnych, także o kształceniu ustawicznym oraz rynku pracy - zawodach, wymaganiach zawodowych, miejscach pracy;

- diagnozowanie preferencji i potencjalnych możliwości zawodowych klienta (często przy użyciu standaryzowanych metod oceny);

- udzielanie rad (o różnym stopniu dyrektywności) dotyczących optymalizowania drogi edukacyjno-zawodowej klienta;

- doradztwo niedyrektywne, służące samopoznaniu i uruchomieniu autorefleksji osoby radzącej się;

- orientację zawodową realizowaną $\mathrm{w}$ ramach programów rozwijających wiedzę i umiejętności osób podejmujących określone decyzje edukacyjno-zawodowe;

- pośrednictwo pracy na linii pracownik-pracodawca;

- rzecznictwo - negocjowanie $\mathrm{w}$ imieniu i na rzecz pracownika $\mathrm{z}$ instytucjami rynku pracy;

- pilotowanie - śledzenie losów absolwentów i wspieranie ich edukacyjno-zawodowej drogi (działania oparte o procedury formalne lub niesformalizowane).

W kontekście powyższych rozważań rodzi się pytanie zasadnicze: $c z y u c z$ niowie szkół zawodowych potrzebuja specyficznego, innego poradnictwa niż pozostali młodzi ludzie obierający inne typy szkót i kierunki kształcenia?

Wydaje się, że w świetle paradygmatu humanistycznego poradnictwa, zakładającego indywidualne, holistyczne traktowanie każdego wspieranego, którego aktywizowanie $\mathrm{w}$ procesie selekcjonowania informacji o rynku pracy, dokonywania autodiagnozy, konstruowania projektów życiowych obejmujących także 
sekwencje decyzji edukacyjnych i zawodowych, odpowiedź na to pytanie nie może być twierdzaca. Cele i zadania oraz założenia poradnictwa karier (zawodowego) w odniesieniu do uczniów szkół zawodowych nie odbiegają od tych dotyczących całej kohorty młodzieży. A czynione wcześniej rozważania objęte są kwantyfikatorem ogólnym. To stwierdzenie nie dowodzi jednak, że na poziomie metodycznym i organizacyjnym nie powinno się stosować metod, form i środków uwzględniających specyficzne potrzeby tej grupy młodych ludzi.

Różne kraje rozwiązują te kwestie w zróżnicowany sposób.

Specyficzne doświadczenia w tym zakresie mają na przykład Niemcy, których system edukacyjny podlega odrębnej polityce poszczególnych landów (a po zjednoczeniu na teren byłych Niemiec Wschodnich przeniesiono rozwiązania z krajów-patronów Niemiec Zachodnich - por. Sałaciński, 2010), ale generalizując - po ukończeniu w wieku 10 lat szkoły podstawowej uczniowie trafiają w mniej więcej wyrównanych proporcjach do trzech rodzajów szkół Hauptschule, która po pięciu latach prowadzi w konsekwencji wprost do nauki zawodu, Realschule - prowadząca po sześciu latach także do nauki zawodu, oraz Gymnasium (liceum) trwające dziewięć lat i prowadzące do kolejnych cykli kształcenia, a także w niektórych landach - Gesamtschule, w których wszyscy uczniowie uczą się w jednej placówce, a w jej ramach $\mathrm{z}$ czasem następuje także dywersyfikacja młodzieży. O wyborze szkoły ponadpodstawowej decyzję podejmują rodzice uczniów w toku negocjacji z nimi samymi, przede wszystkim zaś na podstawie konsultacji z nauczycielami i psychologami szkolnymi.

Wczesne ukierunkowanie kształcenia wymusza jednocześnie wczesne (w początkach adolescencji, tj. w odniesieniu do uczniów 10-11-letnich) wprowadzenie elementów orientacji i poradnictwa zawodowego do szkół. Stanowi ono integralny element systemu nauczania i wychowania, przybierając różne formy na wszystkich szczeblach kształcenia. Głównym ogniwem systemu orientacji i informacji zawodowej są nauczyciele współpracujący $\mathrm{z}$ doradcami zawodowymi $\mathrm{z}$ agencji zatrudnienia. Kładzie się duży nacisk na dostarczenie informacji o rynku edukacji i pracy, przygotowanie młodzieży do samopoznania i podejmowania decyzji karierowych, a także przygotowania do tranzycji z systemu kształcenia na rynek pracy.

Wprowadzenie uczniów w problematykę dotyczącą funkcjonowania świata pracy odbywa się bądź $\mathrm{w}$ ramach wydzielonego obowiązkowego przedmiotu „nauka o pracy”, bądź też treści te włączane są sukcesywnie w zakres różnych przedmiotów. Programy orientacji zawodowej (realizowane w różnych formach) tworzone są $\mathrm{w}$ ścisłym związku $\mathrm{z}$ doradcami $\mathrm{z}$ urzędów pracy, $\mathrm{z}$ nauczycielami i szkolnymi psychologami. Z czasem zajęcia o charakterze orientacyjnym uzupełniane są przez praktyczne przygotowanie do konstruowania kariery, $\mathrm{w}$ ramach którego odbywają się zajęcia praktyczne w warsztatach szkolnych, 
wycieczki do zakładów pracy i centrów informacji zawodowej oraz praktyki w wybranych przedsiębiorstwach. W szkołach poradnictwo zawodowe jest szczególnie rozbudowane. Praktyczna nauka zawodu odbywa się często w pracowniach bezpośrednio powiązanych z konkretnymi przedsiębiorstwami, instytucjami rynku pracy, co daje możliwość uczenia się przez obserwację i uczestniczenia w czynnościach zawodowych pracowników określonych zakładów. Te doświadczenia umożliwiają dokonywanie praktycznej konfrontacji indywidualnych wyobrażeń o określonej pracy z konkretną rolą zawodową oraz sprawdzenie, na ile personalne właściwości predestynują jednostkę do podejmowania określonych czynności zawodowych.

W szkołach różnego typu możliwe jest tworzenie uczniowskich firm, które przyczyniają się do zdobycia praktycznej wiedzy o rynku pracy i uzyskania doświadczeń przydatnych w pracy (Brzozowska, w druku).

W Niemczech znaczna część kształcenia technicznego i zawodowego odbywa się poza systemem oświatowym. „Upraktycznienie” kształcenia w tym kraju (ale i w Austrii, Szwajcarii, Norwegii, Francji, a także w Polsce w ramach nieistniejących już zawodowych szkół przyzakładowych czy w rzemiośle) przejawia się $\mathrm{w}$ promowaniu dualnego systemu edukacji zawodowej polegającego na nauce zawodu poprzez pracę w przedsiębiorstwie, w którym często uzyskuje się później zatrudnienie. System ten realizowany jest na wszystkich poziomach kształcenia. Pozwala to bardzo mocno związać kształcenie z rynkiem pracy i dopasować kwalifikacje pracowników do potrzeb pracodawców. Następuje szybka, konstruktywna konfrontacja wyobrażeń o zawodzie $\mathrm{z}$ realnymi wymaganiami rynku pracy, niepozbawiona wsparcia ze strony konkretnych zakładów pracy ${ }^{3} . \mathrm{Z}$ jednej strony taki stan rzeczy odpowiada na zapotrzebowanie rynku pracy, z drugiej redukuje kształcenie ogólne do niezbędnego minimum, co może przyczyniać się do zawężania pozazawodowych kompetencji młodych ludzi.

Jednym z istotnych elementów działań poradniczych jest budowanie proaktywnej orientacji ucznia oraz uczenie refleksyjnego, świadomego podejmowania decyzji dotyczących przebiegu kariery i ponoszenia odpowiedzialności za dokonywane wybory.

Działalność podmiotów świadczących usługi z zakresu poradnictwa zawodowego regulują liczne przepisy na szczeblu ogólnokrajowym, związkowym i lokalnym ${ }^{4}$.

\footnotetext{
${ }^{3}$ Szerokie rozważania dotyczące specyfiki kształcenia dualnego w krajach Unii Europejskiej zaprezentowała europosłanka Agnieszka Kozłowska-Rajewicz na spotkaniu na Wydziale Studiów Edukacyjnych UAM w dniu 30 października 2015; por. prezentacja w/w autorki: Kształcenie dualne jako narzędzie pokonywania bezrobocia młodych na przykładzie Niemiec i innych krajów UE. Możliwości rozwoju w Polsce.

${ }^{4}$ „Porozumienia ramowe dotyczące współpracy szkół z agencjami poradnictwa zawodowego (Arbeitsagenturen) uchwalane są przez Federalną Agencją Zatrudnienia (Bundesagentur für Arbeit)
} 
W Niemczech postawiono na bardzo rozbudowaną informację zawodową i możliwie wczesne wdrażanie młodzieży do przejmowania odpowiedzialności za własną karierę. Przy tym nie sposób nie zauważyć, że tak realizowane poradnictwo pełni także funkcje systemowe - pozostaje zatem otwarte pytanie o możliwości praktycznego godzenia funkcji makrospołecznych z jednostkowymi potrzebami i indywidualnymi celami życiowymi osób wspieranych.

Eckert H. wskazuje, że

w takim systemie oświatowym poradnictwo zawodowe znajduje się na pograniczu między szkołą ogólnokształcącą a kształceniem zawodowym w przedsiębiorstwie; do zadań poradnictwa należy zarządzanie i równoważenie podaży i popytu na rynku kształcenia zawodowego (...). W ramach tej procedury poradnictwo zawodowe nadal pełni funkcję polegającą na kontrolowaniu społecznej mobilności młodzieży, z jednaj strony starając się jej sprzyjać, z drugiej - weryfikując zasadność dokonanego wyboru. (Guichard, Huteau, 2005: 17)

Inaczej wygląda sprawa poradnictwa zawodowego we Francji. Tamtejszy system oświatowy jest jednolity. W wieku 15-16 lat uczeń podejmuje decyzję o wyborze dalszego profilu kształcenia spośród trzech możliwości - profilu ogólnego, ogólnego technicznego oraz zawodowego. Poradnictwo realizowane w systemie szkolnym wspomaga dokonywanie przez uczniów wyboru dalszego toku kształcenia $\mathrm{w}$ ramach konsultacji $\mathrm{z}$ nauczycielami (kluczowe znaczenie mają tu rezultaty edukacyjne) oraz rodzicami młodych ludzi.

Eckert H., dokonując socjologicznego oglądu tego rozwiązania systemowego, stwierdza:

kontrola nad zawodową zmianą pokoleń, zamiast być pełniona przez instytucje poradnictwa zawodowego, przechodzi w ręce szkoły. Rola instytucji poradnictwa zawodowego coraz częściej sprowadza się do towarzyszenia realizowanemu w szkole procesowi kierowania dalszym losem uczniów na podstawie ich szkolnych osiągnięć. Pojawiają się w związku z tym pytania tego typu: czy doradca zawodu może ograniczać się jedynie do udzielania informacji, czy też powinien iść dalej i interweniować w sferze edukacyjnej, a nawet psychologicznej. (Guichard, Huteau, 2005, s. 18)

Jak pokazują powyższe przykłady, stosuje się w praktyce zróżnicowane organizacyjnie formy poradnictwa, ale i szczegółowy ogląd rzeczywistych efektów makrospołecznych i jednostkowych takiego poradnictwa rodzi szereg pytań i dylematów, które się tu pojawiają. Zasadniczy spośród nich brzmi: w jakim

i Stałą Konferencję Ministrów Edukacji (Kultusministerkonferenz). Na szczeblu krajów związkowych podpisywane są umowy uzupełniające, natomiast na poziomie lokalnym szkoły i urzędy pracy (Arbeitsamt) wraz z podlegającymi im Centrami Informacji Zawodowej (Berufsinformationszentrum) odpowiadają za zapewnienie doradztwa i koordynację świadczonych usług w szkołach, w tym wybór odpowiednich metod, technik i sposobów organizowania poradnictwa zawodowego" (Brzozowska, w druku). 
stopniu możliwe jest realizowanie indywidualnych potrzeb i celów życiowych jednostki w toku konstruowania przez nią personalnej kariery zawodowej, która rozgrywa się w określonych realiach zewnętrznych i specyfikę tych realiów powinna uwzględniać? A na tej kanwie powstaje pytanie o rolę poradnictwa w relacji z uczniem dokonującym wyboru zgodnego z kompetencjami i osobistymi zasobami (chcę, potrafię, mogę), ale nieuwzględniającego ograniczeń zewnętrznych (na przykład wysoka stopa bezrobocia, brak realnego zapotrzebowania na posiadane przez jednostkę kompetencje). A odnosząc te rozważania do realiów polskich - w jakim stopniu poradnictwo powinno wspierać rozbudowane ambicje kształceniowe młodych przejawiające się w motywacji uzyskiwania dyplomów szkół wyższych w sytuacji braku realnego zapotrzebowania na osoby wykonujące niektóre profesje? Czy i w jakim stopniu może (powinno?) ono takim sytuacjom przeciwdziałać, urealniając perspektywę projektowania przyszłości zawodowej przez młodych, „schładzając” ich ambicje edukacyjne i ukierunkowując ich "prorynkowo"? To pytania, na które w realnej perspektywie czasowej przyjdzie nam poszukiwać odpowiedzi.

W kształceniu zawodowym niektóre cykle edukacyjne są relatywnie krótkie, co umożliwia w przypadku błędnych, nietrafionych decyzji życiowych dokonywanie nawet radykalnych zmian, ponowne zdobywanie innych kwalifikacji, komponowanie doświadczeń i zawodowych kompetencji w kształt pożądany z punktu widzenia potrzeb jednostki.

Wydaje się, że związanie edukacji z rynkiem pracy wymaga także wprowadzenia do przedsiębiorstw, zakładów pracy, instytucji rynku pracy zróżnicowanych form poradnictwa, którego celem byłaby pomoc w adaptacji do rzeczywistych warunków pracy, wsparcie $\mathrm{w}$ budowaniu relacji pracowniczych, wyznaczaniu ścieżki kariery w konkretnej instytucji, czy konstruowaniu portfolio zawodowych doświadczeń jednostki. Te formy poradnictwa nie są w polskich realiach praktykowane.

Istotne byłoby permanentne wsparcie (indywidualne, grupowe) umożliwiające uzyskiwanie w ramach całożyciowego procesu „refleksyjności karierowej” (Savickas, Hartung, 2012; Peavy, 2014). Być może pomocne w tym względzie byłyby techniki pracy coachingowej (Surzykiewicz, Kulesza, 2013; Piasecka, 2011) konsekwentnie stosowane $w$ toku przygotowania do dokonywania postanowień zawodowych, w toku przechodzenia na rynek pracy, a następnie konsolidacji $\mathrm{w}$ roli zawodowej w określonym otoczeniu pracowniczym (por. koncepcje Savickasa, Peavy'ego). Dodajmy, wszystkie te składniki kariery (czy w szerszym oglądzie - stadia rozwoju zawodowego wskazane już kilkadziesiąt lat temu przez Supera) zyskują w obecnej rzeczywistości status tymczasowości, a jednostka musi być gotowa na zmiany $\mathrm{w}$ przebiegu kariery, często wielokrotnie. Wymaga to zatem stałego poszukiwania odpowiedzi na pytanie o cele zawodowe, środki 
i możliwości ich realizacji w konkretnym kontekście zewnętrznym, przy wykorzystaniu dobrze rozpoznanego potencjału osobistego, w obrębie zdefiniowanej aktualnej sytuacji biograficznej. Jest to więc specyficzna praca, której materię stanowi przebieg życia jednostki, a jej aktywność autobiograficzna, poszukiwanie zasobów umożliwiających podejmowanie i realizowanie decyzji edukacyjno-zawodowych powinna być wspierana przez działania pedagoga, psychologa, coacha. To z kolei wymaga stałej pogłębionej pracy psychopedagogicznej jednostki nad samą sobą, znacznej dojrzałości i rzeczywistej motywacji warunkującej dokonywanie takiego wglądu. To praca o charakterze coachingowym (czy treningowowarsztatowym) przewidziana na lata, której elementy powinny zaistnieć zarówno w systemie edukacyjnym (także w szkolnictwie zawodowym, jak i w instytucjach rynku pracy.

\section{Literatura}

Bańka A. (2007). Psychologiczne doradztwo karier. Poznań.

Bauman Z. (2006). Plynna nowoczesność. Kraków.

Bauman Z. (2007a). Plynne czasy. Życie w epoce niepewności. Warszawa.

Bauman Z. (2007b). Płynne życie. Kraków.

Beck U. (2002). Społeczeństwo ryzyka. W drodze do innej nowoczesności. Warszawa.

Brzozowska M. (w druku), Uczniowskie firmy systemie orientacji i poradnictwa zawodowego wiemczech.

Cybal-Michalska A. (2013). Młodzież akademicka a kariera zawodowa. Kraków.

Giddens A. (2007). Nowoczesność i tożsamość. „Ja” i społeczeństwo w epoce późnej nowoczesności. Warszawa.

Goźlińska E., Kruszewski A. (2013). Stan szkolnictwa zawodowego w Polsce. Raport. Warszawa.

Guichard J., Huteau M. (2005), Psychologia orientacji i poradnictwa zawodowego. Kraków.

Harwas-Napierała B., Trempała J. (red.). (2014). Psychologia rozwoju człowieka. T. 2. Charakterystyka okresów życia człowieka. Warszawa.

Jeruszka U. (red.). (2012), Unowocześnienie metod i form kształcenia zawodowego w Polsce. Diagnoza i oczekiwane kierunki zmian. Warszawa.

Kaczor S. (1989). Stan i perspektywy szkolnictwa zawodowego w Polsce. Raport Komitetu Ekspertów ds. Edukacji Narodowej. PWN.

Kargulowa A. (2005). O teorii i praktyce poradnictwa. Odmiany poradoznawczego dyskursu. Warszawa.

Kargulowa A. (2009). Pomoc przez porady. Statyczna versus procesualna struktura poradnictwa w przestrzeni życia społecznego. [W:] E. Marynowicz-Hetka (red.). Pedagogika społeczna. Podręcznik akademicki. T. 2. Warszawa.

Kozłowska-Rajewicz A. (2015). Kształcenie dualne jako narzędzie pokonywania bezrobocia młodych na przykładzie Niemiec i innych krajów UE. Możliwości rozwoju w Polsce, prezentacja ze spotkania na WSE UAM w dniu 30.10.2015.

Kwiatkowski S.M. (2001), Kształcenie zawodowe: dylematy teorii i praktyki, IBE, Warszawa

Kwiatkowski S.M. (2008). Kształcenie zawodowe - wyzwania, priorytety, standardy. Warszawa. 
Malewski M. (2003). Poradnictwo wobec zmieniających się wzorów ludzkiego życia. [W:] B. Wojtasik, A. Kargulowa (red). Doradca - profesja, pasja, powołanie. Materiały ze Światowego Kongresu Poradnictwa Zawodowego, Stowarzyszenie Doradców Szkolnych i Zawodowych RP. Warszawa.

Melosik Z. (2014). Kultura popularna i tożsamość młodzieży. W niewoli władzy i wolności. Kraków.

Peavy R.V. (2014). Poradnictwo socjodynamiczne. Praktyczne podejście do nadawania znaczeń. Bielsko-Biała.

Piasecka A. (2011). Coaching jako metoda wsparcia pracownika. [W:] M. Piorunek (red.). Poradnictwo - kolejne przybliżenia. Toruń.

Paszkowska-Rogacz A. (2002). Warsztat pracy europejskiego dorady kariery zawodowej. Warszawa.

Piorunek M. (1992). W poszukiwaniu koncepcji kształcenia zawodowego. „Problemy Rozwoju Edukacji” nr 1.

Piorunek M. (2002). Proeuropäische Kontexte der Reformen auf dem Gebiet der beruflichen Bildung. [W:] W. Thiem (red.). Hoffnungen, Dilemmata und Probleme einer nationalen Schulreform in europäischer Dimension. Potsdam.

Piorunek M. (2004). Projektowanie przyszłości edukacyjno-zawodowej w okresie adolescencji. Poznań.

Piorunek M. (2009). Poradnictwo biograficzne. O pomocy psychopedagogicznej w biegu życia człowieka. „Studia Edukacyjne” nr 9.

Piorunek M. (red.). (2010). Pomoc - wsparcie społeczne - poradnictwo. Toruń.

Piorunek M. (red.). (2011a). Poradnictwo - kolejne przybliżenia. Torun.

Piorunek M. (2011b), (Bez)sens planowania przyszłości... Refleksje o adolescencyjnym projektowaniu przyszłości edukacyjno-zawodowej. „Studia Edukacyjne” nr 18.

Piorunek M. (w druku). Biographical Career Patterns - Differentiations, Emergence. Fields of Empirical Exploration.

Piorunek M., Kozielska J., Skowrońska-Pućka A. (red.). (2013), Rodzina - młodzież - dziecko. Szkice z teorii i praktyki pomocy psychopedagogicznej i socjalnej. Poznań.

Sałaciński L. (2010). Aporie wychowawcze szkoły i nauczyciela. Złudzenia transmisji wartości w edukacji. Zielona Góra.

Savickas M.L. (2010). Life Design: A General Model for Career Intervention in the $21^{\text {st }}$ Century, pdf. DOI: $10.1111 / \mathrm{j} .1556-6676.2012 .00002 . \mathrm{x}$

Savickas M.L. (2013a). The 2012 Leona Tyler award address: constructing careers - actors, agents, and authors. "The Counseling Psychologist" nr 41(4).

Savickas M.L. (red). (2013b). Ten Ideas that Changed Career Development. A Monograph to Celebrate the Centennial of the National Career Development Association (1913-2013). https://associationdatabase.com/aws/NCDA/pt/sd/news_article/82928/_PARENT/layout_det ails_cc/false

Savickas M.L., Hartung P.J. (2012). My Career Story. An Autobiographical Workbook for LifeCareer Success. http://www.vocopher.com/CSI/CCI_workbook.pdf

Surzykiewicz J., Kulesza M. (red.). (2013), Coaching społeczny. W poszukiwaniu efektywnych form wsparcia osób w trudnych sytuacjach życiowych. Warszawa

Szafraniec K. (2011). Młodzi 2011. Warszawa.

Trzeciak W. Drogosz-Zabłocka E. (red.). (1999). Model zintegrowanego poradnictwa zawodowego w Polsce. Warszawa.

Watts A.G. (1996). Careerquake. London.

Watts A.G. (1997). The role of career guidance in societies in transition, „Revista de Pedagogie” nr $1-12$. 